\title{
Halophytes as sources of metals in estuarine systems with low levels of contamination
}

\author{
Thiago Couto $^{\mathrm{A}, \mathrm{C}}$, Bernardo Duarte $^{\mathrm{B}}$, Dimitri Barroso ${ }^{\mathrm{A}}$, Isabel Caçador ${ }^{\mathrm{B}}$ and João C. Marques ${ }^{\mathrm{A}}$ \\ A IMAR - Institute of Marine Research, Department of Life Sciences, Faculty of Sciences and Technology, University \\ of Coimbra, 3004-517 Coimbra, Portugal. \\ ${ }^{\mathrm{B}}$ Centre of Oceanography, Faculty of Sciences, University of Lisbon, Campo Grande, 1749-016 Lisbon, Portugal. \\ ${ }^{\mathrm{C} C o r r e s p o n d i n g ~ a u t h o r . ~ E m a i l: ~ t h i a g o c @ u c . p t ~}$
}

This paper originates from a presentation at the COST WG2 Meeting 'Putting halophytes to work-genetics, biochemistry and physiology' Hannover, Germany, 28-31 August 2012.

\begin{abstract}
Heavy metal concentrations present in the above- and beowground tissues of Scirpus maritimus L., Spartina maritima (Curtis) Fernald and Zostera noltii Hornem were analysed seasonally in the Mondego Estuary, Portugal. The sediments of the estuary were confirmed to contain only low concentrations of heavy metals. The belowground tissues of all three species showed higher heavy metal concentrations than the aboveground tissues. Although the sediments only contained low levels of contamination, because the area occupied by $S$. maritimus and Z. noltii was large, significant quantities of heavy metals were accumulated and exported to the surrounding water bodies. In contrast with observations of highly contaminated estuaries, it was found that in spite of the low level of contaminants in the sediments of the Mondego Estuary, aquatic vegetation functioned as a source of metals for nearby systems.
\end{abstract}

Additional keywords: estuary, halophytes, heavy metal, Portugal.

Received 9 October 2012, accepted 18 February 2013, published online 15 March 2013

\section{Introduction}

The approval of the Water Framework Directive (WFD) requires the member states of the European Union (EU) to monitor the biological quality of all of their water bodies and elaborate a management plan for their river basins to prevent potential problems (EC 2000). The WFD CIS (2003) advises that, in transitional waters (TW), the intertidal areas from the highest tide limit to the lowest tide limit should be included in the monitoring program, which encompasses salt marshes.

Salt marshes are natural deposits of heavy metals in an estuarine system (Caçador et al. 1996; Doyle and Otte 1997). When located near polluted areas, these ecosystems receive large amounts of pollutants from industrial and urban wastes, which either drift downstream with the river flow or are dumped directly from nearby industrial and urban areas (Reboreda and Caçador 2007). When metals enter salt marshes, they spread through the system with the tides and periodic floods and interact with the sediment and the biotic community (Suntornvongsagul et al. 2007; Caçador et al. 2012). Most salt marsh plants accumulate large amounts of metals in both their aerial and belowground organs (Caçador et al. 2000). Salt marsh species greatly influence the inputs and outputs of metals and nutrients in the marsh (Caçador et al. 2004; Reboreda and Caçador 2007; Reboreda et al. 2008; Sousa et al. 2008; Caçador et al. 2009) owing to the different uptake rates of these elements. As the highest levels of metal accumulation are found in the root tissues (Caçador et al. 2000; Reboreda and Caçador 2007), the decomposition of root litter may also be a source of metals released to the surrounding sediment through leaching (Weis and Weis 2004; Pereira et al. 2007). Metals are not well studied in the Mondego Estuary and so it is important to know if the system has some kind of metal contamination. Scirpus maritimus L., Spartina maritima (Curtis) Fernald and Zostera noltii Hornem together occupy $~ 50 \%$ of the area (J Neto, unpubl. data), covering a large part of the salt marsh, making these three species very important in the system.

The present study considers the dynamics of $S$. maritimus, $S$. maritima and $Z$. noltii in order to evaluate their primary production and senescence mechanisms and their implications for metal cycling at the estuarine level. In this work we report the metal concentrations in the salt marsh sediments of the Mondego Estuary and the role of plants in metal cycling in the estuarine system.

\section{Materials and methods}

Study area

The Mondego Estuary (Fig. 1) is a temperate system located in the central Atlantic coast of Portugal $\left(40^{\circ} 08^{\prime} \mathrm{N}, 8^{\circ} 50^{\prime} \mathrm{W}\right)$ (Marques and Nogueira 1991). The terminal portion of the estuary, $7 \mathrm{~km}$ long and 2-3 km across at its widest, consists of two arms (North and South) with highly divergent hydrological characteristics 


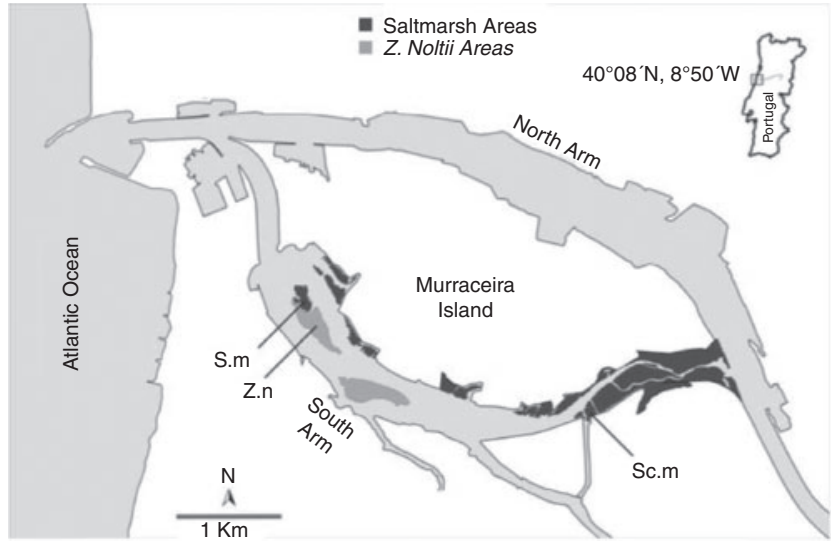

Fig. 1. Terminal part of the Mondego Estuary, Portugal, showing Zostera noltii (Z.n), Spartina maritima (S.m) and Scirpus maritimus (Sc.m) sampling location indicated by the arrows.

separated by the Murraceira Island (Marques et al. 2003). The South arm is shallower than the North arm (2-4 m during high tide), is characterised by large areas of intertidal mudflats (almost $75 \%$ of the area) exposed during low tide (Neto et al. 2008), contains sediments with high percentages of silt and clay and is considered a rich estuarine habitat in terms of productivity and biodiversity (Marques et al. 1993).

\section{Sampling and laboratory procedures}

For each sampling, three sediment cores $(50 \mathrm{~cm}$ depth) were taken in pure stands of Spartina maritima (Curtis) Fernald, Zostera noltii Hornem and Scirpus maritimus L. The stands were located along the marsh, with a minimum distance of $10 \mathrm{~m}$ between each stand. All samples were collected during low tide. Pure stands of $Z$. noltii, $S$. maritima and $S$. maritimus were sampled in the spring, summer and autumn of 2010 and the winter of 2011. The aboveground biomass was assessed for each species by clipping out three $0.3 \times 0.3 \mathrm{~m}$ squares. Three additional sediment cores were also taken to sample belowground biomass at each species site using a tubular probe with an $8 \mathrm{~cm}$ diameter for sampling the first $30 \mathrm{~cm}$, which contains the majority of belowground components (Caçador et al. 2004). The belowground plant material was carefully separated from the sediment under a stream of water, using a sieve with a $212 \mu \mathrm{m}$ mesh size to remove any adhering particulate matter, and then was washed with Milli-Q water $(18.2 \Omega \mathrm{U} \mathrm{cm})$. Plant organs were oven-dried at $60^{\circ} \mathrm{C}$ and powdered in a grinding ball mill (Glen Crestom MM2000, London, UK) (Gross et al. 1991). Sediment samples were oven-dried at $60^{\circ} \mathrm{C}$ until constant weight ( 3 days). After the oven, the sediments were cleaned of roots with tweezers, passed through a $0.25 \mathrm{~mm}$ mesh, homogenised and ground with an agate mortar.

Pore water was extracted by centrifugation at $6704 \mathrm{~g}$ for $10 \mathrm{~min}$ at $4^{\circ} \mathrm{C}$ and the salinity was estimated using a refractometer (Atago, S/Mill-E; Borivali, Mumbai, India). The sediment organic matter content was determined in dried samples by loss on ignition (LOI) at $600^{\circ} \mathrm{C}$ for $2 \mathrm{~h}$, following the method described by Caçador et al. (2000). Sediment grain size was determined by mechanical sequential sediment-sieving, using analytical sieves housed in a shaker, to evaluate the relative abundance (Folk 1954) and were classified as coarse sand $(\geq 0.5 \mathrm{~mm})$, fine + medium sand $(>0.063$ and $<0.5 \mathrm{~mm})$ and silt + clay $(<0.063 \mathrm{~mm})$. Sediment samples $(\sim 100 \mathrm{mg})$ were mineralised with $2 \mathrm{~mL}$ of $\mathrm{HNO}_{3} / \mathrm{HCl}(3: 1 \mathrm{v} / \mathrm{v})$ at $110^{\circ} \mathrm{C}$. Plant samples were digested with $2 \mathrm{~mL}$ of $\mathrm{HNO}_{3} / \mathrm{HClO} 4(7: 1 \mathrm{v} / \mathrm{v})$ at $110^{\circ} \mathrm{C}$ (Duarte et al. 2011). Metal concentrations (copper, zinc, lead, cobalt, cadmium and chromium) were determined by flame atomic absorption spectrometry (FAAS, Duisburg, Germany) with an air-acetylene flame. International certified reference materials (CRM145, CRM 146 and BCR 62) were used to ensure accuracy, and precision was determined by analysing replicate samples. Trace metal concentrations in the reference materials determined by FAAS were not statistically different from the certified values (Student's $t$-test; $\alpha=0.05$ ).

\section{Data analysis}

Above and belowground net primary production (NPP, g) for each species were calculated according to Caçador et al. (2007), using Eqn 1, where the minimum biomass value found in the work period was subtracted of the maximum biomass value found in the same period:

$$
\mathrm{NPP}=\text { maximum biomass }- \text { minimum biomass. }
$$

The root decomposition was calculated as percentage of NPP (grams) using the following formula:

$$
\begin{aligned}
& \text { Root decomposition } \\
& =\left(1-\frac{\text { Minimum root biomass }}{\text { Maximum root biomass }}\right) \times \text { Root NPP. }
\end{aligned}
$$

Aboveground biomass losses (g) were assessed for the biomass lost during senescence, using the biomasses recorded as described above for root decomposition (Eqn 2). Metal pools $(\mathrm{mg})$ were determined by multiplying the biomass of a sample at time $t$ by the metal content per mg at time $t$ to assess the effective amount of metal retained in the plants:

$$
\text { metal pool }=\left[\text { metal }_{\mathrm{t}} \times \text { biomass }_{\mathrm{t}} .\right.
$$

Metal primary accumulation (MPA, mg) was calculated according to the following equation using the maximum and minimum metal pool values verified during the sampling season:

$$
\text { MPA = maximum metal pool - minimum metal pool. }
$$

Metal exports (mg) were calculated as a percentage of MPA (Eqn 4) as described above, taking into account the percentage of mass losses due to decomposition of the belowground (metal export $_{\text {dec }}$ ) or senescence of the aboveground organs (metal export $\left._{\text {sen }}\right)$ :

$$
\begin{aligned}
& \text { metal export }_{\text {dec }}=\text { root decomposition } \times \text { root MPA, } \\
& \text { metal export } \text { sen } \\
& =\text { aboveground senescence } \times \text { aboveground MPA. }
\end{aligned}
$$

To calculate an annual balance between the vegetation and the sediment, an average metal concentration was derived for the sediment. Metal returns to the sediment due to biomass losses 
(root decomposition and aboveground organs decomposition) were determined as by Wen-jiao et al. (1997):

$$
\text { Metal return }=\left(\frac{\text { Export rate } \times \text { MPA }}{\text { Metal concentration in sediment }}\right)
$$

The cycling coefficient and turnover period were also calculated according to Wen-jiao et al. (1997) and Válega et al. (2008).

$$
\text { Cycling coefficient }=\frac{\text { Metal returned due to litter fall }}{\text { MPA }}
$$

The biomass parameters (NPP and maximum biomass) were used to determine the turnover rate of each plant part, while the metal accumulation parameters (MPA and metal pool) were used to assess the turnover rate of each metal pool:

$$
\text { Turnover rate }=\frac{\text { NPP or MPA }}{\text { Maximum biomass or metal pool }}
$$

\section{Statistical analysis}

To check for differences between the biomasses and the metal contents, one-way ANOVA tests were employed using the software Statplus ver. 5.8 (AnalystSoft Inc., Vancouver, Canada). A non-metric multidimensional scaling (nMDS) was analysed together with the ANOVA for a better view of the metal concentration between species results. The nMDS analyses were performed using the PRIMER ver. 6 (Primer-E Ltd., Lutton, Ivybridge, UK).

\section{Results}

\section{Sediment characteristics}

Grain size composition in the $S$. maritimus zone was composed of $\sim 32 \%$ of coarse sand, $55 \%$ of fine + medium sand and $13 \%$ by silt + clay. In contrast, Z. noltii showed low values of coarse sand $(5 \%)$ but high values of fine + medium sand $(73 \%)$ and silt + clay particles composed $22 \%$ of the sediment in the $Z$. noltii area. Similar to that in $Z$. noltii area, in the rhizosediments colonised by S. maritima a low proportion for coarse sand (9\%) was found, but the results for fine + medium sand $(53 \%)$ were similar to those under S. maritimus; the percentage found for silt + clay was $38 \%$, and higher than for the other two species.

\section{Biomass production}

Regarding plant biomass (Fig. 2; Table 1), both S. maritimus and S. maritima had significantly higher biomass values in their belowground rather than in their aboveground organs $(P<0.05)$. $S$. maritimus always presented the highest belowground biomass, with a maximum during the spring season. When comparing the belowground NPP values of the three species, significant differences were only found between $S$. maritimus and $Z$. noltii $(P<0.05)$. The NPP mean value of S. maritimus $\left(1010 \mathrm{~g} \mathrm{~m}^{-2}\right)$ was more than three times higher than that of $Z$. noltii $\left(270 \mathrm{~g} \mathrm{~m}^{-2}\right)$. The highest value of NPP (Table 1) for the aboveground organs was found in $S$. maritimus, followed by $S$. maritima and $Z$. noltii. All differences between the NPP of the aboveground organs were significant $(P<0.05)$. Turnover rates for aboveground organs were significantly different $(P<0.05)$ between all species pairs except $S$. maritimus and $S$. maritima. There were no significant differences in turnover rates for belowground organs.

\section{Heavy metal concentrations in plants}

S. maritima showed higher $(P<0.05)$ metal concentrations in the belowground organs than in the aboveground organs (Fig. 3), with the exception of $\mathrm{Cu}$, for which the difference was not significant. This species had seasonal differences $(P<0.05)$ for $\mathrm{Co}$ and $\mathrm{Cr}$ in above and belowground organs, but not for the others metals. The highest average concentration for the majority of

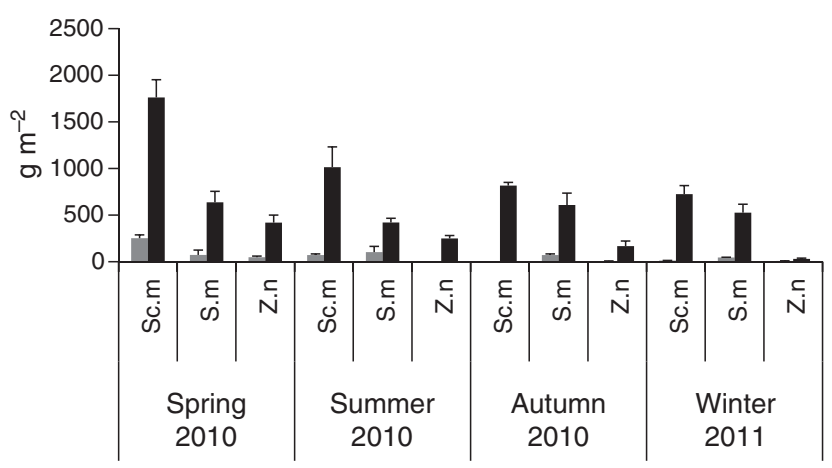

Fig. 2. Above- and belowground seasonal biomass average (grey, aboveground; black, belowground) of the three studied species over 1 year period and s.d. Sc.m, Scirpus maritimus; S.m, Spartina maritima; Z.n, Zostera noltii.

Table 1. Biomass $\left(\mathrm{g} \mathrm{m}^{-2}\right)$ for each season, NPP $\left(\mathrm{g} \mathrm{m}^{-2}\right)$ and turnover $\left(\mathrm{g} \mathrm{m}^{-2}\right) \pm$ standard deviation

\begin{tabular}{|c|c|c|c|c|c|c|}
\hline & Spring & Summer & Autumn & Winter & NPP & Turnover $\left(\right.$ year $\left.^{-1}\right)$ \\
\hline \multicolumn{7}{|c|}{ Aboveground organs } \\
\hline S. maritimus ${ }^{* * * *}$ & $252 \pm 35$ & $70 \pm 13$ & & & $190 \pm 90^{* *}$ & $0.76 \pm 0.09$ \\
\hline S. maritima ${ }^{* *}$ & $72 \pm 51$ & $102 \pm 61$ & $71 \pm 11$ & $45 \pm 2$ & $80 \pm 30^{* *}$ & $0.77 \pm 0.28$ \\
\hline Z. noltii ${ }^{*, * *}$ & $47 \pm 12$ & $2 \pm 0.55$ & $5 \pm 1.8$ & $8 \pm 1$ & $70 \pm 52^{* *}$ & $1.53 \pm 0.35^{* *}$ \\
\hline \multicolumn{7}{|c|}{ Belowground organs } \\
\hline S. maritimus ${ }^{* *}$ & $1761 \pm 191$ & $1014 \pm 216$ & $815 \pm 34$ & $887 \pm 278$ & $1010 \pm 330^{* * *}$ & $0.66 \pm 0.15$ \\
\hline S. maritima ${ }^{* *}$ & $637 \pm 116$ & $420 \pm 45$ & $607 \pm 127$ & $526 \pm 90$ & $600 \pm 340^{* *}$ & $0.73 \pm 0.19$ \\
\hline Z. noltii ${ }^{*, * *}$ & $419 \pm 81$ & $249 \pm 31$ & $167 \pm 54$ & $31 \pm 12$ & $270 \pm 200^{* *}$ & $0.66 \pm 0.13^{* *}$ \\
\hline
\end{tabular}
Statistical seasonal differences $\left(^{*}, P<0.05\right)$. Above- and belowground organs statistically different from each other in all seasons $(* *, P<0.05)$ 

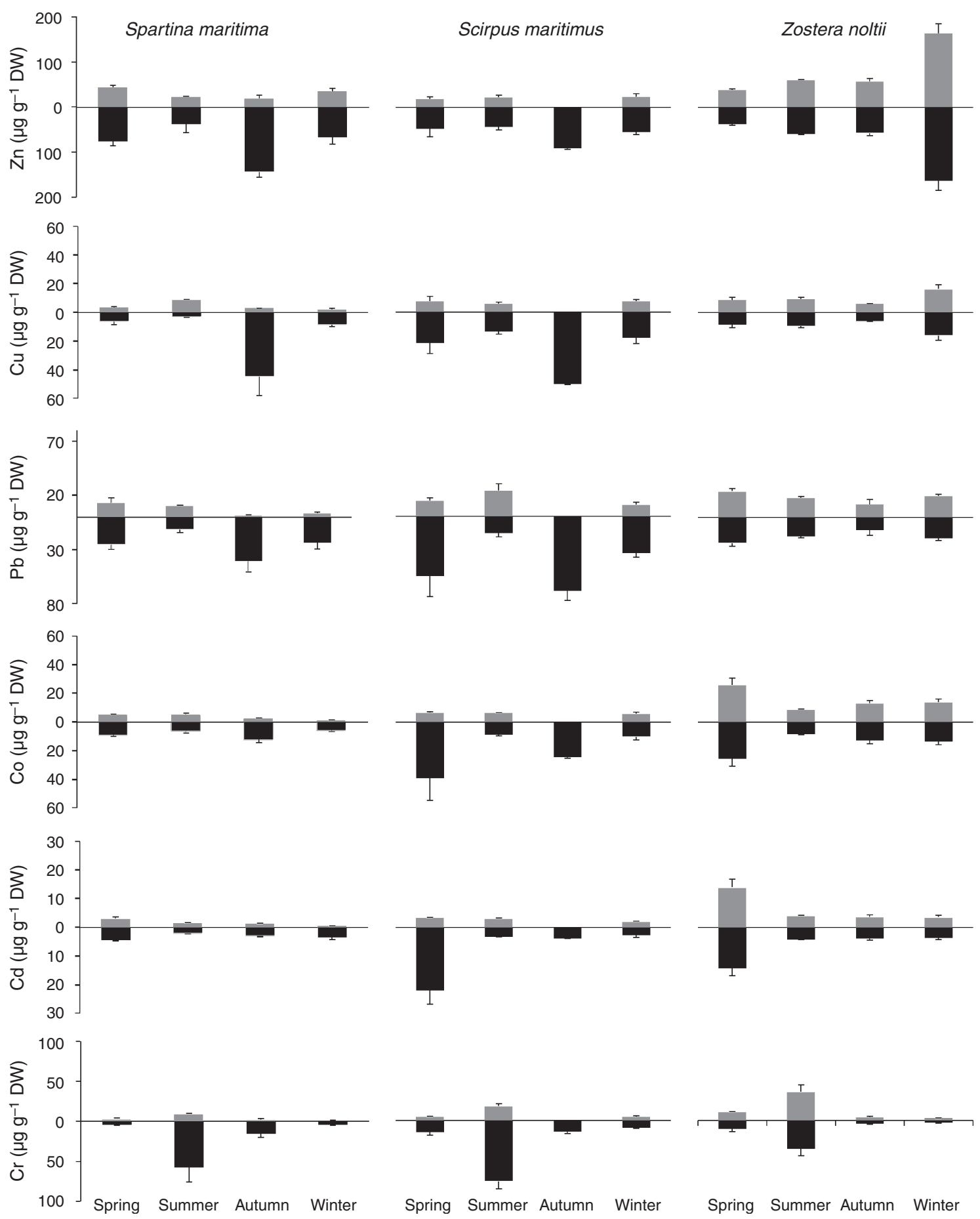

Fig. 3. Above- and belowground seasonal metal concentration average for Scirpus maritimus, Zoostera noltii and Spartina maritima and s.d. over 1 year period. (grey, aboveground organs; black, belowground organs).

analysed metals ( $\mathrm{Zn}, \mathrm{Cu}, \mathrm{Pb}$ and $\mathrm{Co}$ ) occurred in autumn and the lowest in summer. $S$. maritimus exhibited similar behaviour to S. maritima, with higher $(P<0.05)$ metal concentration in the belowground organs (Fig. 3). Except for $\mathrm{Cu}$, where the difference was not significant, $S$. maritimus, presented seasonal differences $(P<0.05)$ for all metals, and had half of the analysed metals $(\mathrm{Zn}$,
$\mathrm{Cu}$ and $\mathrm{Pb}$ ) with their highest average concentration in autumn. Like the other two species, $Z$. noltii showed significant seasonal variation of metal concentrations $(P<0.05)$ for the majority of studied metals. The above- and belowground organs, in this species had similar concentrations $(P>0.05)$ (Fig. 3). Figure 4 shows the differences that occured between species, showing that 


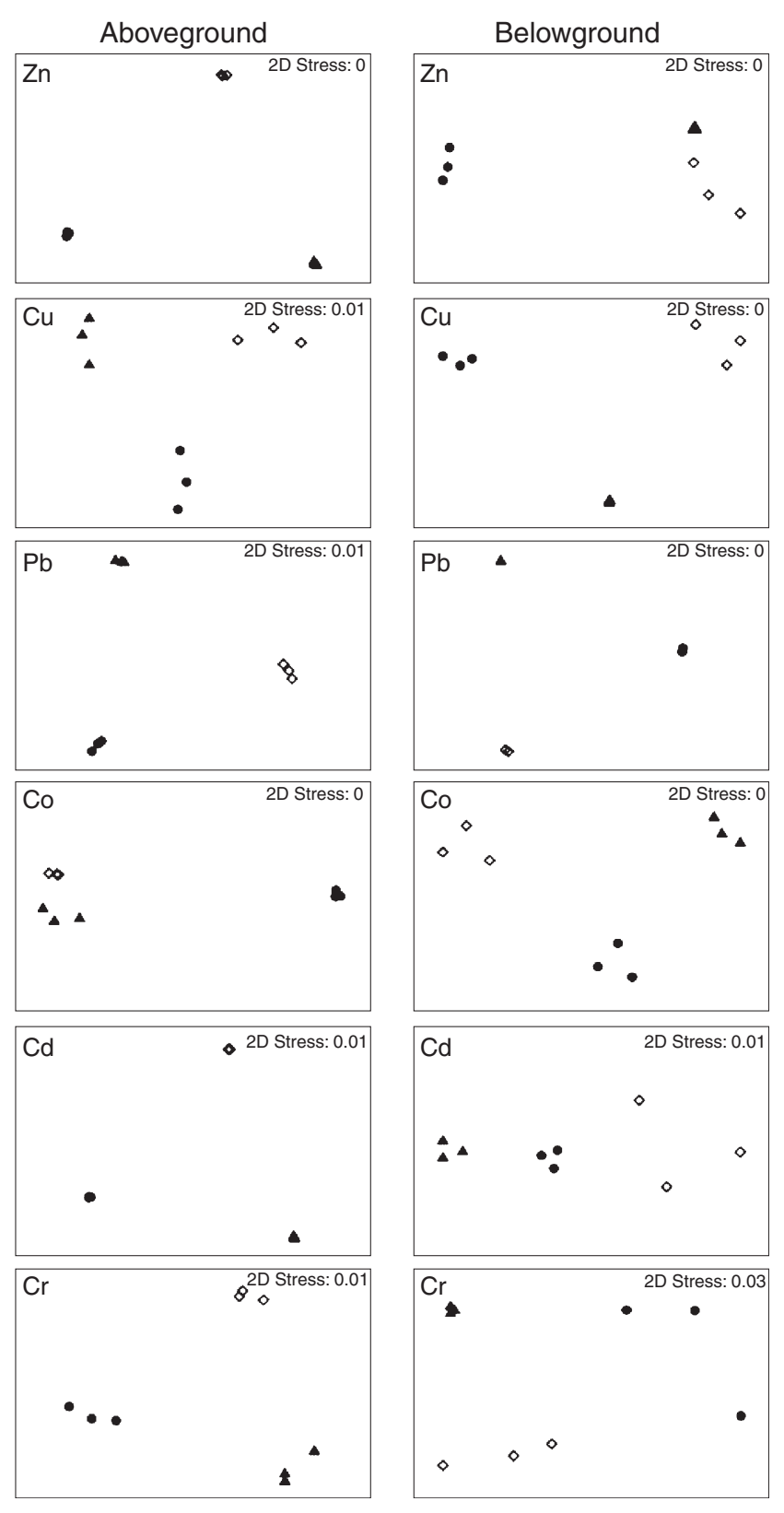

Fig. 4. nMDS of the metal concentrations for the above and belowground organs in the three studied species for one year period. $\mathbf{\Delta}$, Scirpus maritimus; $\diamond$, Spartina maritima; $\bullet$, Zoostera noltii.

pratically for all metals the species were separated from each other. Half of analysed metals ( $\mathrm{Pb}, \mathrm{Co}$ and $\mathrm{Cd})$ had their highest average values in spring.

\section{Heavy metal concentration in sediments}

Significant differences $(P<0.05)$ were found between the sediment heavy metal concentrations of the three studied species for all metals except $\mathrm{Zn}$ and $\mathrm{Cd}$. These two elements were found to be the most and least abundant elements ( $\mathrm{Zn}$ and $\mathrm{Cd}$ respectively) in the sediments, whereas the other metals had similar concentrations. Sediments colonised by $S$. maritimus presented the highest values for all metals, with the exception of Cd (Fig. 5). Cu had a higher concentration than $\mathrm{Cr}(P<0.05)$ between the sediments under $S$. maritimus and $S$. maritima. All metal levels, with the exception of zinc and cadmium, were significantly different $(P<0.05)$ between the sediments under $S$. maritimus and $Z$. noltii. In comparison with the elemental composition of the Earth's crust (Turekian and Wedepohl 1961), only $\mathrm{Pb}$ and $\mathrm{Cd}$ were enriched in the sediments (twice for $\mathrm{Pb}$ and 30 times for $\mathrm{Cd}$ ).

\section{Heavy metal cycling}

The metal primary accumulation (MPA) and exports for the aboveground and belowground organs of each species studied are shown in Fig. 6. In S. maritimus aboveground organs, all of the accumulated metals were exported to the sediment or water column. A similar behaviour was observed in $Z$. noltii, which accumulated only small amounts of metals in its aboveground and belowground organs, whereas $S$. maritima showed a lower exportation rate. High accumulation values occurred in the belowground organs of both $S$. maritima and S. maritimus. With the exception of $\mathrm{Cr}, S$. maritimus had a higher aboveground turnover rate for all metals than S. maritima. When comparing $S$. maritimus and $Z$. noltii, only Co and $\mathrm{Cd}$ aboveground turnover rates showed significant differences $(P<0.05)$. Only $\mathrm{Zn}$ and $\mathrm{Pb}$ rates showed statistically significant differences $(P<0.05)$ between $S$. maritimus and $S$. maritima, whereas only $\mathrm{Cr}$ rates showed significant differences $(P<0.05)$ between $Z$. noltii and $S$. maritima. For the metal cycling coefficient (Table 2) of the aboveground organs, S. maritimus had higher values for $\mathrm{Cu}, \mathrm{Pb}$ and $\mathrm{Cr}$, whereas $Z$. noltii had higher values for $\mathrm{Zn}, \mathrm{Co}$ and $\mathrm{Cd}$. For the belowground organs, $S$. maritima showed higher values for $\mathrm{Zn}$ and $\mathrm{Cu}$, and $\mathrm{S}$. maritimus had higher values for $\mathrm{Pb}, \mathrm{Co}, \mathrm{Cd}$ and $\mathrm{Cr}$. With the exception of the comparison between $S$. maritimus and S. maritima aboveground organs for zinc, all other cycling coefficient comparisons did not show significant differences $(P>0.05)$. Table 3 shows the amounts of metals retained and exported by each species. With an estuarine coverage area of $\sim 16.4$ ha, S. maritimus accumulated more than $2 \mathrm{~kg}$ of each of the analysed metals in one year, with $\mathrm{Pb}$ being the most retained metal. S. maritima, with an area of 2.8 ha, retained more $\mathrm{Zn}$, with a total of $1.8 \mathrm{~kg}$ in 1 year, and $Z$. noltii, with an area of 10.4 ha, accumulated more zinc and cobalt.

\section{Discussion}

Although the absolute heavy metal concentrations in the sediments of the Mondego Estuary are very low, if the extent of the plant coverage is considered, the heavy metal concentrations in plant biomass acquire new ecological importance.

As previously noted for other halophytes in other coastal systems (Caçador et al. 2009; Duarte et al. 2010), higher amounts of plant biomass were found in the belowground than the aboveground organs. When plants accumulate metals, the roots and rhizomes generally show higher concentrations than the aboveground parts (Sinicrope et al. 1992). This behaviour could be seen in other studies like Reboreda et al. (2008) and Duarte et al. (2010). It was also confirmed that heavy metal accumulation 

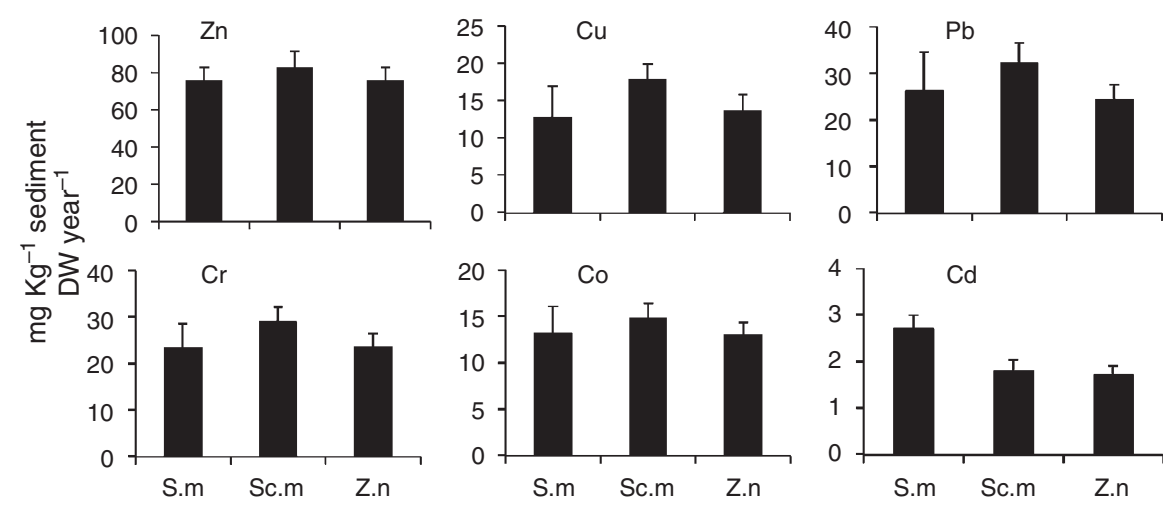

Fig. 5. Average metal concentrations in sediment for 1 year period and s.d. (S.m, Spartina maritima; Sc.m, Scirpus maritimus; Z.n, Zostera noltii).

Scirpus maritimus
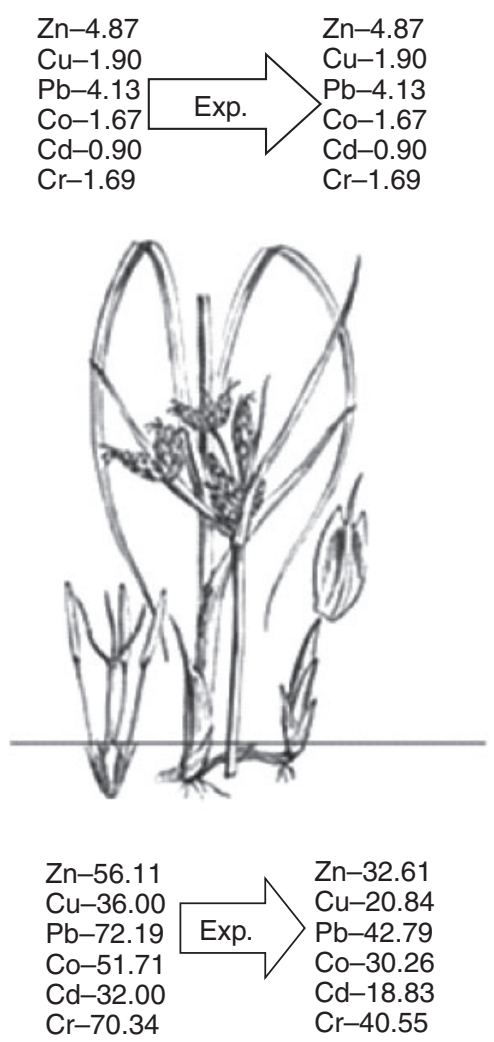

Spartina maritima
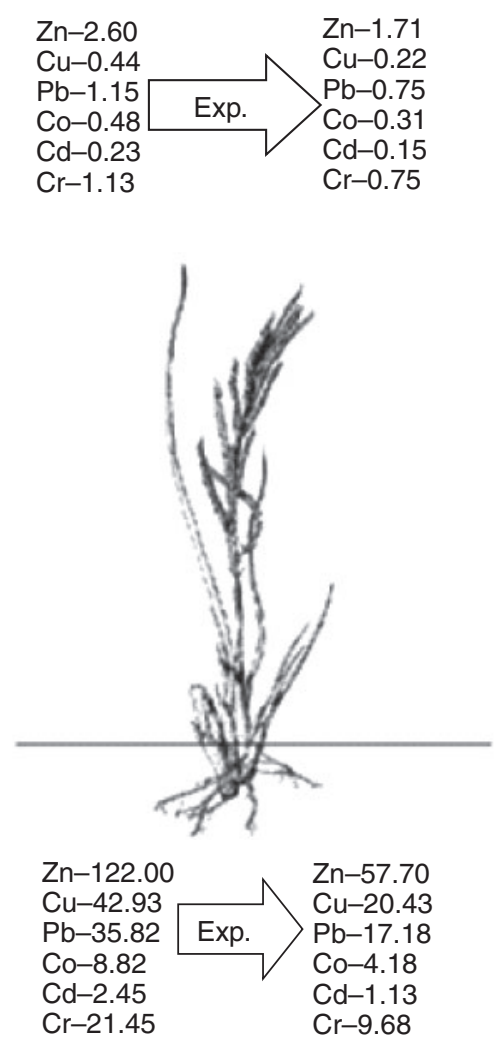

Zostera noltii

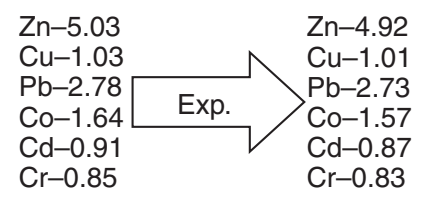

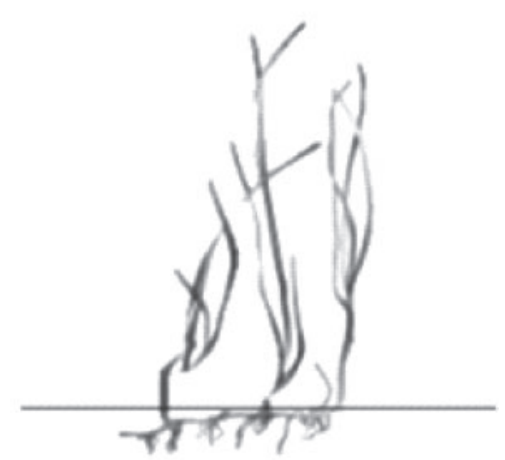

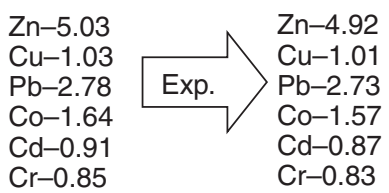

Fig. 6. Metal primary accumulation (MPA, $\mathrm{mg} \mathrm{m}^{-2}$ ) and exports of each studied species, for above- (values at top) and belowground (values at bottom) organs. Exp., export.

is not strictly independent of biomass production (Caçador et al. 2009; Duarte et al. 2010). Although all species presented similar patterns of biomass production, with higher values during spring and lower values towards the winter, $S$. maritimus is peculiar in that it completely loses all of its aboveground biomass during the autumn. This life history trait likely has implications on the ecosystem metal budget, as all of the aboveground biomass in areas colonised by $S$. maritimus is converted into necromass and exported to the adjacent water column.
Because of the very different areas colonised by each of the investigated halophytes, these endogenous processes are of great importance when addressing the metal budgets between sediments, halophytes and the estuary. Heavy metals absorption in seagrasses appears to be influenced by seasons (Larkum et al. 2006). What was corroborated by the results in this study, was that seasonal differences occurred in Z. noltii metal concentrations. This species also presented high biomass exportation percentages. Zostera individuals can become 
Table 2. Mean cycling coefficient values \pm s.d. for all the studied species for each metal in 1 year period Significant differences between above- and belowground organs are indicated: *, $P<0.05$

\begin{tabular}{lcccccc}
\hline \multicolumn{1}{c}{$\mathrm{Zn}$} & \multicolumn{1}{c}{$\mathrm{Cu}$} & \multicolumn{1}{c}{$\mathrm{Pb}$} & \multicolumn{1}{c}{$\mathrm{Co}$} & $\mathrm{Cd}$ & $\mathrm{Cr}$ \\
\hline Aboveground organs & & & & & & \\
Scirpus maritimus & $0.058 \pm 0.005^{*}$ & $0.106 \pm 0.015^{*}$ & $0.128 \pm 0.005^{*}$ & $0.113 \pm 0.007^{*}$ & $0.505 \pm 0.006^{*}$ & $0.058 \pm 0.005^{*}$ \\
Zostera noltii & $0.063 \pm 0.004$ & $0.073 \pm 0.002$ & $0.112 \pm 0.003$ & $0.121 \pm 0.009$ & $0.512 \pm 0.061$ & $0.035 \pm 0.007$ \\
Spartina maritima & $0.007 \pm 0.003^{*}$ & $0.016 \pm 0.006^{*}$ & $0.028 \pm 0.003^{*}$ & $0.023 \pm 0.009^{*}$ & $0.785 \pm 0.057$ & $0.032 \pm 0.019^{*}$ \\
Belowground organs & & & & & & \\
Scirpus maritimus & $0.381 \pm 0.082^{*}$ & $1.137 \pm 0.015^{*}$ & $1.297 \pm 0.085^{*}$ & $2.051 \pm 0.097^{*}$ & $10.470 \pm 0.689^{*}$ & $1.395 \pm 0.275^{*}$ \\
Zostera noltii & $0.063 \pm 0.004$ & $0.073 \pm 0.002$ & $0.112 \pm 0.003$ & $0.121 \pm 0.009$ & $0.512 \pm 0.061$ & $0.035 \pm 0.007$ \\
Spartina maritima & $0.744 \pm 0.140^{*}$ & $1.595 \pm 0.006^{*}$ & $0.629 \pm 0.244^{*}$ & $0.317 \pm 0.079^{*}$ & $0.825 \pm 0.023$ & $0.414 \pm 0.082^{*}$ \\
\hline
\end{tabular}

Table 3. MPA, export and accumulation for all the studied species in their total area for each metal (g)

\begin{tabular}{|c|c|c|c|c|c|c|c|c|}
\hline Species & MPA/export & Organ & $\mathrm{Zn}$ & $\mathrm{Cu}$ & $\mathrm{Pb}$ & Co & $\mathrm{Cd}$ & $\mathrm{Cr}$ \\
\hline \multirow{5}{*}{ Scirpus maritimus } & MPA & Aboveground & 799 & 311 & 677 & 273 & 147 & 277 \\
\hline & & Belowground & 9205 & 5906 & 11843 & 8483 & 5250 & 11540 \\
\hline & Export & Aboveground & 799 & 311 & 677 & 273 & 147 & 277 \\
\hline & & Belowground & 5350 & 3419 & 7020 & 4964 & 3089 & 6652 \\
\hline & Accumulated & Total & 3855 & 2487 & 4823 & 3519 & 2160 & 4887 \\
\hline \multirow[t]{5}{*}{ Spartina maritima } & MPA & Aboveground & 751 & 127 & 332 & 138 & 6 & 32 \\
\hline & & Belowground & 3526 & 1241 & 1035 & 254 & 70 & 620 \\
\hline & Export & Aboveground & 494 & 635 & 21 & 896 & 4 & 21 \\
\hline & & Belowground & 1667 & 590 & 496 & 120 & 32 & 279 \\
\hline & Accumulated & Total & 1884 & 656 & 550 & 139 & 40 & 351 \\
\hline \multirow[t]{5}{*}{ Zostera noltii } & MPA & Aboveground & 527 & 108 & 291 & 171 & 95 & 89 \\
\hline & & Belowground & 527 & 108 & 291 & 171 & 95 & 89 \\
\hline & Export & Aboveground & 515 & 105 & 286 & 164 & 91 & 87 \\
\hline & & Belowground & 515 & 105 & 286 & 164 & 91 & 87 \\
\hline & Accumulated & Total & 24 & 6 & 10 & 14 & 8 & 4 \\
\hline
\end{tabular}

detached from sediments due to extreme events (Den Hartog 1987). This process has enormous implications due to the vast areas covered by Zostera meadows along the Mondego Estuary and the biomass exported during these events. Additionally, it is important to consider that the entire plant is exported during these Zostera release events, not only the aboveground organs, suggesting that the amount of heavy metal-contaminated biomass exported at these events is comparable to that assessed for S. maritimus.

Solís et al. (2007) found similar metal concentration for above and belowground organs in the seagrass Thalassia testudinum. Similar behaviour was noted in Z. noltii in the present work, but for the other two studied species, the aboveground biomass presented lower metal values in comparison with the belowground biomass, which is in agreement with previous studies (Duarte et al. 2010). Our results showed that the heavy metal concentrations were higher in the belowground organs (in agreement with Cambrollé et al. 2008; Reboreda et al. 2008; Duarte et al. 2010) of both $S$. maritimus and S. maritima, which suggests the ability to accumulate heavy metals; in contrast, $Z$. noltii showed similar concentration levels in both aboveground and belowground organs but still accumulated metal. The three studied species presented higher belowground biomass values in the spring than the other seasons, and many of the heavy metal concentrations were higher in autumn and winter. The absorption and exportation by the three species did not show significant differences, demonstrating that all species absorb and export metals at similar quantity.

With the exception of the contents of the aboveground organs of S. maritimus (which are washed out due to senescence), the remaining two species showed low turnover, indicating that metal cycling between roots and sediments occurs at a rather slow pace. The annual mean of all of the sediment heavy metal concentration values found in this work was low in comparison with other estuaries around the world, such as Kyeongi Bay in Korea (Ahn et al. 1995), Sheldt in the Netherlands (Van Alsenoy et al. 1993), Thames in the UK (Attrill and Thomes 1995), Port Philip Bay (Talbot et al. 1976), the Bilbao Estuary (Cearreta et al. 2000) and Jurujuba (Baptista Neto et al. 2000). Indeed, all of the heavy metal values in the salt marsh of the Mondego Estuary are below the limits prescribed in the Guidance on the assessment and redevelopment of contaminated land (ICRLC 1987). Zhang et al. (2001), in the intertidal sediment of Scirpus mariqueter and Scirpus trigueter, also had higher values for $\mathrm{Cu}$ and $\mathrm{Zn}$ than the values found in this work for $S$. maritimus. Another example can be found in the work of Izquierdo et al. (1997), where higher values of $\mathrm{Cu}, \mathrm{Zn}, \mathrm{Pb}, \mathrm{Cd}$ and $\mathrm{Cr}$ in the Odiel (Spain) salt marsh sediment were found. Mondego salt marsh has very low values of 
these six heavy metals ( $\mathrm{Zn}, \mathrm{Cu}, \mathrm{Pb}, \mathrm{Cd}, \mathrm{Co}$ and $\mathrm{Cr}$ ) and can therefore be used as a reference for non-contaminated salt marshes. Although rather low concentrations of heavy metals were verified in the salt marsh sediments, the plants of the ecosystem function not only as a sink for heavy metal retention, but as a source, exporting metals to nearby systems.

\section{Conclusion}

The role of halophytic plants as metal sinks, mostly through their root systems, is well known in contaminated salt marshes. The Mondego Estuary salt marshes have relatively low heavy metal concentrations in their sediments. This system is also largely colonised by two species of aquatic vegetation with high biomass exportation rates, either due to senescence mechanisms (S. maritimus) or physical factors ( $Z$. noltii). Although the amount of metals taken up by the aquatic vegetation is relatively low, the exportation of biomass has enormous implications on system contamination at the estuarine level. From analysis of the concentration of metals in the above and belowground organs and in the sediment it was possible to conclude that the Mondego Estuary, although low in contaminants, could act as a source of metals for nearby systems.

\section{Acknowledgements}

The authors would like to thank to the 'Fundação para a Ciência e Tecnologia (FCT)' for funding the research in the Centre of Oceanography throughout the project PEst-OE/MAR/UI0199/2011 and in the Institute of Marine research (IMAR) throughout the project PEst-C/MAR/UI0284/2011 and this specific work throughout the project 3M RECITAL (LTER/BIA-BEC/0019/2009). T. Couto investigation was supported by FCT throughout a PhD grant (SFRH/ $\mathrm{BD} / 64608 / 2009)$.

\section{References}

Ahn IY, Kang YC, Choi JW (1995) The influence of industrial effluents on intertidal benthic communities in Panweol, Kyeonggi Bay (Yellow Sea) on the west coast of Korea. Marine Pollution Bulletin 30, 200-206. doi:10.1016/0025-326X(94)00125-S

Attrill MJ, Thomes RM(1995) Heavy metal concentrations in sediment from the Thames Estuary, UK. Marine Pollution Bulletin 30, 742-744. doi:10.1016/0025-326X(95)98339-X

Baptista Neto JA, Smith BJ, McAllister JJ(2000) Heavy metal concentrations in surface sediments in a nearshore environment of Jurujuba Sound, Brazil. Environmental Pollution 109, 1-9. doi:10.1016/S0269-7491 (99)00233-X

Caçador I, Vale C, Catarino F (1996) The influence of plants on concentration and fractionation of $\mathrm{Zn}, \mathrm{Pb}$, and $\mathrm{Cu}$ in salt marsh sediments (Tagus Estuary, Portugal). Journal of Aquatic Ecosystem Health 5, 193-198. doi:10.1007/BF00124106

Caçador I, Vale C, Catarino F (2000) Seasonal variation of Zn, Pb, Cu and Cd concentrations in the root-sediment system of Spartina maritima and Halimione portulacoides from Tagus Estuary salt marshes. Marine Environmental Research 49, 279-290. doi:10.1016/S0141-1136(99) 00077-X

Caçador I, Costa A, Vale C (2004) Carbon storage in Tagus saltmarsh sediments. Water Air and Soil Pollution Focus 4, 701-714. doi:10.10 23/B:WAFO.0000028388.84544.ce

Caçador I, Costa A, Vale C (2007) Nitrogen sequestration capacity of two salt marshes from the Tagus estuary. Hydrobiologia 587, 137-145. doi:10. 1007/BF00124106
Caçador I, Caetano M, Duarte B, Vale C (2009) Stock and losses of trace metals from salt marsh plants. Marine Environmental Research 67, 75-82. doi:10.1016/j.marenvres.2008.11.004

Caçador I, Costa JL, Duarte B, Silva G, Medeiros JP, Azeda C, Castro N, Freitas J, Pedro S, Almeida PR, Cabral H, Costa MJ (2012) Macroinvertebrates and fishes as biomonitors of heavy metal concentration in the Seixal Bay (Tagus Estuary): which species perform better? Ecological Indicators 19, 184-190. doi:10.1016/ j.ecolind.2011.09.007

Cambrollé J, Redondo-Gómez S, Mateos-Naranjo E, Figueroa ME (2008) Comparison of the role of two Spartina species in terms of phytostabilization and bioaccumulation of metals in the estuarine sediment. Marine Pollution Bulletin 56, 2037-2042. doi:10.1016/ j.marpolbul.2008.08.008

Cearreta A, Irabien MJ, Leorri E, Yusta I, Croudace IW, Candy AB (2000) Recent anthropogenic impacts on the Bilbao Estuary, Northern Spain: geochemical and microfaunal evidence. Estuarine, Coastal and Shelf Science 50, 571-592. doi:10.1006/ecss. 1999.0582

Den Hartog C (1987) 'Wasting disease' and other dynamic phenomenain Zostera beds. Aquatic Botany 27, 3-14. doi:10.1016/0304-3770(87) 90082-9

Doyle M, Otte M (1997) Organism-induced accumulation of Fe, Zn and As in wetland soils. Environmental Pollution 96, 1-11. doi:10.1016/S02697491(97)00014-6

Duarte B, Caetano M, Almeida PR, Vale C, Caçador I (2010) Accumulation and biological cycling of heavy metal in four salt marsh species, from Tagus Estuary (Portugal). Environmental Pollution 158, 1661-1668. doi:10.1016/j.envpol.2009.12.004

Duarte B, Freitas J, Caçador I (2011) The role of organic acids in assisted phytoremediation processes of salt marsh sediments. Hydrobiologia 674, 169-177. doi:10.1007/s10750-011-0731-3

EC (2000) Directive 2000/60/EC of the European Parliament and of the Council Establishing a Framework for Community Action in the Field of Water Policy. PE-CONS3639/1/00 REV 1 EN.

Folk RL (1954) The distinction between grain size and mineral composition in sedimentary rock nomenclature. Journal of Geology 62(4), 344-359. doi: $10.1086 / 626171$

Gross M, Hardisky M, Wolf P, Klemas V (1991) Relationship between aboveground and belowground biomass of Spartina alterniflora (smooth cordgrass). Estuaries 14, 180-191. doi:10.2307/1351692

ICRLC (1987) Guidance on the Assessment and Redevelopment of Contaminated Land. Guidance Note 59/83. Department of Environment, London.

Izquierdo C, Usero J, Gracia I (1997) Speciation of heavy metals in sediments from salt marshes on the Southern Atlantic Coast of Spain. Marine Pollution Bulletin 34, 123-128. doi:10.1016/S0025-326X(96) 00059-8

Larkum AWD, Orth RJ, Duarte CM(2006) 'Seagrasses: biology, ecology and conservation.' (Springer: Dordrecht, The Netherlands)

Marques JC, Nogueira A (1991) Life cycle, population dynamics, and production of Echinogammarus marinus (Leach) (Amphipoda) in the Mondego Estuary (Portugal). Acta Oceanologica 11, 213-223.

Marques JC, Maranhão P, Pardal MA (1993) Human impact assessment on the subtidal macrobenthic community structure in the Mondego Estuary (Western Portugal). Estuarine, Coastal and Shelf Science 37, 403-419. doi:10.1006/ecss. 1993.1064

Marques JC, Nielsen SN, Pardal MA, Jørgensen SE (2003) Impact of eutrophication and river management within a framework of ecosystem theories. Ecological Modelling 166, 147-168. doi:10.1016/S0304-3800 (03)00134-0

Neto JM, Flindt MR, Marques JC, Pardal MA (2008) Modelling nutrient mass balance in a temperate meso-tidal estuary: implications for management. Estuarine, Coastal and Shelf Science 76, 175-185. doi:10.1016/ j.ecss.2007.06.013 
Pereira P, Caçador I, Vale C, Caetano M, Costa AL (2007) Decomposition of belowground litter and metal dynamics in salt marshes (Tagus Estuary, Portugal). The Science of the Total Environment 380, 93-101. doi:10. 1016/j.scitotenv.2007.01.056

Reboreda R, Caçador I (2007) Halophyte vegetation influences in salt marsh retention capacity for heavy metals. Environmental Pollution 146, 147-154. doi:10.1016/j.envpol.2006.05.035

Reboreda R, Caçador I, Pedro S, Almeida PR (2008) Mobility of metals in salt marsh sediments colonised by Spartina maritima (Tagus Estuary, Portugal). Hydrobiologia 606, 129-137. doi:10.1007/s10750-008-93 40-1

Sinicrope TL, Langis R, Gersberg RM, Busnardo MJ, Zedler JB (1992) Metal removal by wetland mesocosms subjected to different hydroperiods. Ecological Engineering 1, 309-322. doi:10.1016/09258574(92)90013-R

Solís C, Martínez A, Lavoisier E, Martínez MA, Isaac-Olivé K (2007) Trace metal analysis in sea grasses from Mexican Caribbean Coast by particle induced X-ray emission (PIXE). Revista Mexicana de Física 54(1), 50-53.

Sousa AI, Lillebø AI, Caçador I, Pardal MA (2008) Contribution of Spartina maritima to the reduction of eutrophication in estuarine system. Environmental Pollution 156, 628-635. doi:10.1016/j.envpol.2008. 06.022

Suntornvongsagul K, Burke DJ, Hamerlynck AP, Hahn D (2007) Fate and effects of heavy metals in salt marsh sediments. Environmental Pollution 149, 79-91. doi:10.1016/j.envpol.2006.12.010
Talbot V, Magee RJ, Hussain M (1976) Distribution of heavy metals in Port Philip Bay. Marine Pollution Bulletin 7, 53-55. doi:10.1016/0025-326X (76)90093-X

Turekian KK, Wedepohl KH (1961) Distribution of the elements in some major units of the Earth's crust. Geological Society of America Bulletin 72, 175-191. doi:10.1130/0016-7606(1961)72[175:DOTEIS]2.0.CO;2

Válega M, Lillebø A, Pereira M, Caçador I, Duarte A, Pardal M (2008) Mercury mobility in a salt marsh colonized by Halimione portulacoides. Chemosphere 72, 1607-1613. doi:10.1016/j.chemosphere.2008.04.007

Van Alsenoy V, Bernard P, Van Grieken R (1993) Elementary concentrations and heavy metal pollution in sediments and suspended matter from the Belgian North Sea and Scheldt Estuary. The Science of the Total Environment 133, 153-181. doi:10.1016/0048-9697(93)90119-Q

Weis JS, Weis P (2004) Metal uptake, transport and release by wetland plants: implications for phytoremediation and restoration. Environment International 30, 685-700. doi:10.1016/j.envint.2003.11.002

Wen-jiao Z, Xiao-yong C, Peng L (1997) Accumulation and biological cycling of heavy metal elements in Rhizophora stylosa mangroves in Yingluo Bay, China. Marine Ecology Progress Series 159, 293-301. doi:10.3354/meps 159293

WFD CIS (2003) Overall approach to the classification of ecological status and ecological potential. Guidance Document No. 13. Directorate General Environment of the European Commission, Brussels.

Zhang W, Yu L, Hutchinson SM, Xu S, Chen Z, Gao X (2001) China's Yangtze Estuary: I. Geomorphic influence on heavy metal accumulation in intertidal sediments. Geomorphology 41, 195-205. doi:10.1016/ S0169-555X(01)00116-7 